\title{
In vitro SCREENING ANTIBACTERIAL ACTIVITY OF Bidens pilosa LINNÉ AND Annona crassiflora MART. AGAINST OXACILLIN RESISTANT Staphylococcus aureus (ORSA) FROM THE AERIAL ENVIRONMENT AT THE DENTAL CLINIC
}

\begin{abstract}
SUMMARY
Currently multiresistant Staphylococcus aureus is one common cause of infections with high rates of morbidity and mortality worldwide, which directs scientific endeavors in search for novel antimicrobials. In this study, nine extracts from Bidens pilosa (root, stem, flower and leaves) and Annona crassiflora (rind fruit, stem, leaves, seed and pulp) were obtained with ethanol: water (7:3, v/v) and their in vitro antibacterial activity evaluated through both the agar diffusion and broth microdilution methods against 60 Oxacillin Resistant S. aureus (ORSA) strains and against S. aureus ATCC 6538. The extracts from B. pilosa and A. crassiflora inhibited the growth of the ORSA isolates in both methods. Leaves of $B$. pilosa presented mean of the inhibition zone diameters significantly higher than chlorexidine $0.12 \%$ against ORSA, and the extracts were more active against $S$. aureus ATCC $(p<0.05)$. Parallel, toxicity testing by using MTT method and phytochemical screening were assessed, and three extracts (B. pilosa, root and leaf, and A. crassiflora, seed) did not evidence toxicity. On the other hand, the cytotoxic concentrations $\left(\mathrm{CC}_{50}\right.$ and $\left.\mathrm{CC}_{90}\right)$ for other extracts ranged from 2.06 to 10.77 $\mathrm{mg} / \mathrm{mL}$. The presence of variable alkaloids, flavonoids, tannins and saponins was observed, even though there was a total absence of anthraquinones. Thus, the extracts from the leaves of B. pilosa revealed good anti-ORSA activity and did not exhibit toxicity.
\end{abstract}

KEYWORDS: Plant extracts; Products with antimicrobial action; Staphylococcus aureus; ORSA; Toxicity tests; Microbial sensitivity tests.

\section{INTRODUCTION}

Staphylococcus aureus is found in the human microbiota and may become pathogenic under certain conditions. It is a human pathogen distinguished by its ability to cause infection in virtually every tissue and organ system of the body, leading to serious illnesses ${ }^{24,41}$. The use of methicillin and other synthetic penicillins, such as oxacillin started in 1959, and represented a significant step in antistaphylococcal therapy worldwide. However, the identification of strains of Methicillin-resistant S. aureus (MRSA) was recorded in 1962 (hereafter called Oxacillinresistant $S$. aureus [ORSA]), thus spreading fast around the world in subsequent years. From the 1980s, the occurrence of ORSA infections increased considerably in several countries, and strains of ORSA have assumed increasing importance internationally. In addition, at present, besides having established itself as an important hospital pathogen, it is now beginning to prevail in the wider community as well, becoming one common cause of infections with high rates of morbidity and mortality throughout the world $3,6,60$.

Resistance can be intrinsic to a bacterium, or acquired through mutations or by the incorporation of new genes. The increasing prevalence of nosocomial infections caused by ORSA/MRSA during the last two decades throughout the world has been associated with the widespread occurrence of specific strains of ORSA/MRSA international ${ }^{1}$. Based on the genotyping techniques of electrophoresis in pulsed-field gel (EPFG), SCCmec typing and multilocus typing sequence, several pandemic MRSA clones were identified, including the Iberian (ST247-SCCmecIA), Brazilian (ST239-III), New York/Japan (ST5-II), Pediatric (ST5-IV), EMRSA-16 (ST36-II), EMRSA-15 (ST22-IV), and Berlin (ST45-IV) clones $^{1,19,35}$. Studies from Brazil showed the predominance of BEC, a multi-resistant clone first described in Brazil, in 1992, which accounted for $70-80 \%$ of total isolates of ORSA/MRSA in Brazilian hospitals ${ }^{20,58}$.

Dissemination of ORSA strains is one of the major health issues faced by a great number of countries and the phenomenon of the multiresistance is becoming alarming. Until today, it has been observed there are an increasing number of studies related to the epidemiology of this microorganism in centers or in intensive care units which include immunocompromised patients who have undergone surgical intervention, who have been transplanted or who are suffering from severe burns highlighting the

(1) Microbiology and Immunology Department, Biomedical Science Institute, Federal University of Alfenas, Alfenas, MG, Brazil.

(2) Research Laboratory of Genetics and Molecular Biology, University José do Rosário Vellano, Alfenas, MG, Brazil.

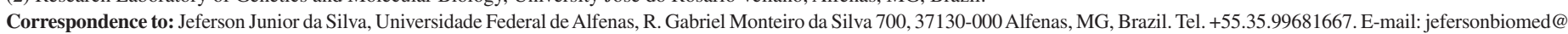
hotmail.com 


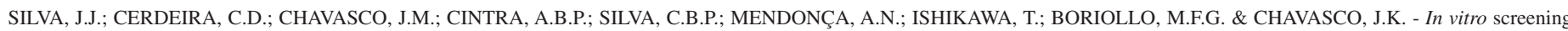
antibacterial activity of Bidens pilosa Linné and Annona crassiflora Mart. against Oxacillin Resistant Staphylococcus aureus (ORSA) from the aerial environment at the dental clinic. Rev. Inst. Med. Trop. Sao Paulo, 56(4): 333-40, 2014.

need for the development of drugs that are effective in treating these infections ${ }^{6,33,39}$. To overcome the problem of the multiresistance of the microorganisms, scientific efforts have been made. Nevertheless, for implementation in medical particle, little has been achieved.

The study of antimicrobial agents on plants has great importance and is crucial in several sectors of pharmaceutical sciences and cosmetics. Furthermore, plants are strong candidates in studies of bioprospecting and the use of data from such studies as a first step to the discovery of the pharmacological activity for new antimicrobial agents is extremely important, especially in a country like Brazil that offers a huge biodiversity to be analyzed, but only a few of these have been scientifically investigated ${ }^{5,31,32,37}$.

Bidens pilosa Linné (family Asteraceae), commonly called "picãopreto" is a medicinal plant native to South America that nowadays is distributed all over the world, mainly in tropical and subtropical regions ${ }^{16}$. It is a small erect annual herb growing up to $1.5 \mathrm{~m}$ high. Considered as a weed in many places, it has bright green leaves with serrated prickly edges and produces small yellow flowers ${ }^{42}$. This plant is widely used either in traditional medicine or folk medicine by indigenous people to treat a variety of illnesses including pain, fever, angina, diabetes, edema (water retention), infections, inflammation, anti-flu and in gastroenteritis treatment ${ }^{10,29}$. Extensive researches over the past decades have shown that B. pilosa has activities: antiviral ${ }^{11}$, antifungal ${ }^{18,40}$ and antibacterial ${ }^{23,28,48}$. Some classes of compounds, such as flavonoids and polyacetylenes, were isolated from the B. pilosa and are generally associated in the pharmacological activities of this plant ${ }^{16,22,44,51}$.

Annona crassiflora Mart., 1841, popularly known as "Araticum" or "marolo" or "field araticum", is a member of the Annonaceae family found in the Brazilian Cerrado, with socio-economic and medicinal importance. The traditional use of this plant includes the treatment of wounds, venereal diseases, snakebites, louses and, furthermore, it can act as an antimicrobial, antidiarrheal and antirheumatic ${ }^{61}$. SANTOS et al. ${ }^{50}$ isolated and determined the structure of a new acetogeninase, a prototype substance from the ethanol extract seeds, which was named crassiflorina or araticulin. There have been many studies done to elucidate the biological actions of acetogeninases: RUPPRECHET et al. ${ }^{49}$ and ZAFRA-POLO et al. ${ }^{64}$ relate them to cytotoxic, antimitotic, antimicrobial and antimalarial; MORRE $e t$ $a l .{ }^{38}$ and OBERLIES et al. ${ }^{43}$ reported antitumor activity in in vitro and in vivo with different strains of cancer cells, and some acetogeninases were effective in the inactivation of multiresistant cell strains to certain drugs without causing toxicity in other human cells.

Because of an increase in the microbial resistance to antimicrobials available, as well as the limited therapeutic alternatives, there is a need to search for novel substances with antimicrobial activity. In this context, this study had as its aim to evaluate the in vitro antibacterial activity of hydroethanolic extracts from medicinal plants found in the Cerrado of Minas Gerais State (Bidens pilosa Linné and Annona crassiflora Mart.) against ORSA strains, isolates from the environmental sources (dental clinic) previously characterized and genotyped, besides the evaluation of the resistant profile of the strains to antibiotics utilized in medical particles. In addition, the toxicity and phytochemistry profile of the extracts were assessed.

\section{MATERIALS AND METHODS}

Obtaining the ORSA samples: A total of 60 ORSA samples $(n=60)$ from an aerial environment have been isolated at the Integrated Dental Clinic, characterized and maintained at the Research Laboratory of Genetics and Molecular Biology, both at the University José do Rosário Vellano in Alfenas-MG. These samples obtained were collected using Petri plates $(90 \mathrm{~mm} \pm 15 \mathrm{~mm}$ ) containing $20 \mathrm{~mL}$ of Mannitol salt agar (Merck), exposed for two hours during two shifts, from two hours after the beginning of each shift, and strategically placed in Dental Clinics. The identity of Staphylococcus aureus species was obtained using the classical microbiology methods. Additionally, a confirmatory test was carried out to evaluate the resistance to oxacillin, suggestive of the mec A gene presence by screening the Mueller-Hinton Agar supplemented culture with $684 \mathrm{mM} \mathrm{NaCl}(4 \% \mathrm{w} / \mathrm{v})$ and oxacillin $\left(6 \mu \mathrm{g} \mathrm{mL}^{-1}\right)$ similar to the method described previously by NCCLS, current Clinical and Laboratory Standards Institute (CLSI) in the document M7-A6 ${ }^{12}$, in which the standard strain of $S$. aureus ATCC 25923 oxacillin-susceptible was also used to ensure reproducibility and accuracy. These isolates were kept in the permanent culture $-70^{\circ} \mathrm{C}$. At the time of analysis when utilized against the plant extracts, it was reactivated.

Collecting of the plants: Chart 1 shows the coordinates where the samples of B. pilosa and A. crassiflora were collected. After collecting the plants used in this work, they were identified, registered and filed at the Herbarium of the UALF in the Federal University of Alfenas by Prof. Dr. Marcelo Polo.

Preparation of the extracts: The plants' parts from B. pilosa (root, stem and flower) and $A$. crassiflora (rind fruit, stem, seed, pulp and leaf) were cleaned and cut manually, then were mixed at a concentration of $20 \%$ weight/volume of ethyl alcohol $70 \%$. Next, they were macerated for seven days and kept in the dark with daily shaking. After maceration, they received filtration through "nylon" and again through a paper filter. Subsequently, the extracts were subjected to evaporation and concentration under the negative pressure of $500 \mathrm{mmHg}$ and $60^{\circ} \mathrm{C}$. They were then distributed in five $\mathrm{mL}$ bottles, frozen and lyophilized, whereby yielding dried crude hidroalcoholic extracts. The powders were stored at $20{ }^{\circ} \mathrm{C}$ and finally, before testing, were solubilized in water.

Chart 1

Data of collection places and identification of Bidens pilosa and Annona crassiflora analyzed

\begin{tabular}{|c|c|c|c|c|c|}
\hline Family & Specie & Collection place & Coordinates & Collection date & Exsicata number \\
\hline Asteraceae & Bidens pilosa Linné & Pouso Alegre city, MG & $\begin{array}{l}22^{\circ} 27^{\prime} 75^{\prime \prime} \mathrm{S} \\
18^{\circ} 45^{\prime} 90^{\prime \prime} \mathrm{W}\end{array}$ & January, 2011 & 1745 \\
\hline Annonaceae & Annona crassiflora Mart. (1841) & Alterosa city, MG & $\begin{array}{l}21^{\circ} 850^{\prime} 18^{\prime \prime S} \\
46^{\circ} 513^{\prime} 06^{\prime \prime W}\end{array}$ & March, 2011 & 1401 \\
\hline
\end{tabular}




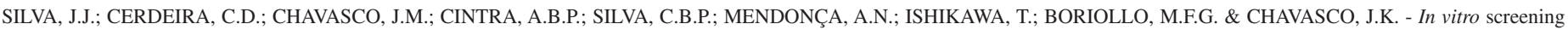

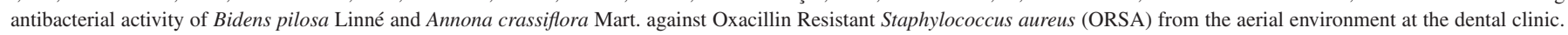
Rev. Inst. Med. Trop. Sao Paulo, 56(4): 333-40, 2014.

Screening of antibacterial activity: In vitro microbiological tests were performed at the Laboratory of Microbiology and Immunology of the Federal University of Alfenas. Firstly, the isolates were inoculated in specific Vogel Johnson agar (with potassium tellurite), submitted to a confirmation of the $S$. aureus specie by tests of biochemistry screening (tests of catalase, coagulase and DNase) and method of Gram. Susceptibility testing to antibiotics was conducted by using a method described previously by BAUER and KIRBY ${ }^{4}$. The antibacterial activity of the extracts was evaluated through agar diffusion following the document CLSI $^{12}$ with modifications according to SILVA et al. ${ }^{56}$ (Fig. 1). Suspensions of overnight-cultured ORSA isolates were prepared in saline solution $(0.9 \% \mathrm{NaCl})$ with a turbidity corresponding to a 0.5 tube of Mac-Farland scale and inoculated on the surface of culture medium Mueller-Hinton Agar with the help of swabs. Forty $\mu \mathrm{L}$ of these extracts (at a concentration of $100 \mathrm{mg} / \mathrm{mL}$ ) were placed in wells of four $\mathrm{mm}$ diameter made in the culture medium. The plates were incubated at 37 ${ }^{\circ} \mathrm{C}$ for 18 hours. After incubation, the reading of growth inhibition zone diameters was performed, by using chlorhexidine solution at $0.12 \%$ as a positive control, and distilled water as a negative control. The standard strain of $S$. aureus ATCC 6538 susceptible to the oxacillin was also used with the aim of making a comparison.

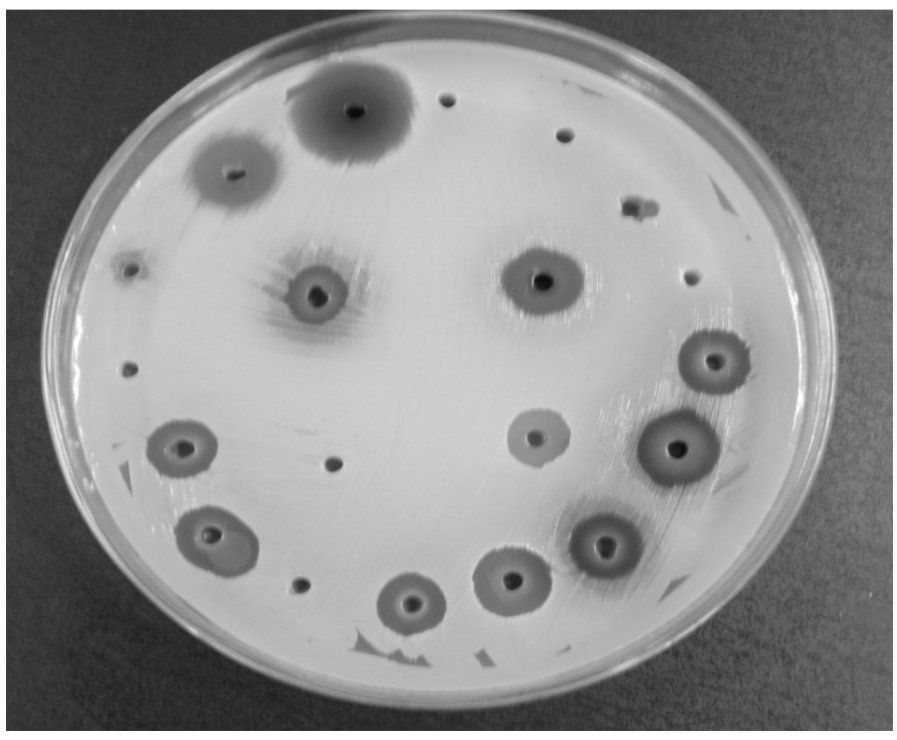

Fig. 1 - Determination of the antimicrobial activity of plant extracts according to the methodology of SILVA et al., 2010.

All extracts were submitted to the minimum inhibitory concentration (MIC) by using broth microdilution methodology as proposed in document M7A6 ${ }^{12}$. This methodology was used to evaluate the susceptibility of the 60 ORSA samples. The test was carried out in sterile microdilution plates with 96 flat bottomed wells, composed of eight series identified from A to $\mathrm{H}$, each one with twelve wells. Firstly, 100 $\mu \mathrm{L}$ of Mueller Hinton broth medium was dispensed into the wells on a microplate. Afterwards the extracts were diluted consecutively into the wells of the plate with a concentration ranging from 50 to $0.09 \mathrm{mg} / \mathrm{mL}$. The suspensions of overnight-cultured of ORSA isolates were suspended in saline solution with the turbidity adjusted. They were then dispensed into the wells at a volume of $10 \mu \mathrm{L}$ per well. The columns 11 and 12 were reserved as controls. The control of the growth promotion was composed of $100 \mu \mathrm{L}$ broth plus $10 \mu \mathrm{L}$ of the inoculums, the control of sterility was composed of $100 \mu \mathrm{L}$ of the culture medium, and the control of extract was composed of $100 \mu \mathrm{L}$ of the culture medium plus $100 \mu \mathrm{L}$ of extract. The plates were incubated at $37^{\circ} \mathrm{C}$ for 24 hours. The readings were made visually comparing the growth of the microorganisms in the wells numbered one to ten with the controls as recognized by CLSI ${ }^{12}$. The lowest concentration that produced a significant inhibition of the growth was established as the MIC value.

Cytotoxicity screening - MTT method: The cytotoxicity was assessed by using the MTT method (3-(4,5-Dimethylthiazol-2-yl)-2,5diphenytetrazoliumbromide). Briefly, in accordance with ARAUJO et $a .^{2}$, in this test, $1 \times 10^{4}$ cells (derived from Aedes albopictus mosquito larvae) were seeded per well in 96-well tissue culture plates containing $0.1 \mathrm{~mL}$ of L-15 medium supplemented with $1 \%$ of fetal bovine serum and with decreasing dilutions from these extracts (5 to $0.039 \mathrm{mg} / \mathrm{mL}$ ). For cell control, only the medium was added. After incubation, $10 \mu \mathrm{L}$ of MTT was added to the wells and incubated for four hours at room temperature, in order to incorporate the MTT for the formation of the formazan crystals. Spectrophotometric analysis was performed by using a reading at a wavelength of $600 \mathrm{~nm}$. The percentage of cytotoxicity was calculated using the formula [(AB) / AX100], where A and B are values of optical densities of treated and controlled cells, respectively. So, the $50 \%$ cytotoxic $\left(\mathrm{CC}_{50}\right)$ and $90 \%$ cytotoxic $\left(\mathrm{CC}_{90}\right)$ concentrations were calculated and defined as the concentration of the extract that reduced the absorbance of treated cells in 50\% and 90\% respectively, when compared with those of the cell control.

Evaluation of phytochemical profile of the extracts: The qualitative analyses of chemical substances of the extracts analyzed were determined by colorimetric methods and/or precipitator, according to $\operatorname{COSTA}^{13}$. These methodologies were selected to determine the presence of alkaloids, anthraquinones, flavonoids, tannins, and saponins

Statistical Analysis: The agar diffusion tests were realized in triplicate and the results were statistically analyzed using Sisvar Software Version 5.3. With the aim of comparing the means, the ANOVA analysis followed by SCOTT \& KNOTT ${ }^{55}$ as a post test were performed, and the means were statistically different when $p<0.05$.

\section{RESULTS}

ORSA samples: All the 60 samples analyzed in this experiment were properly confirmed as Oxacillin Resistant Staphylococcus aureus (ORSA) through a method recognized for definition of resistance to oxicillin. Furthermore, the susceptibility profile of the samples to the different groups of antibiotics, commonly used in the clinic, was investigated by an antibiogram. In Figure 2 it can be observed its heterogeneous multidrug resistance to several classes of the antibiotics analyzed. Resistance to vancomycin, Azithromycin, and amoxicillin with clavulanic acid were presented for 40, 53.3, and $40 \%$ of 60 samples respectively. It was observed there was a significant intermediate resistance of the isolated to ciprofloxacin and clindamycin.

Screening of antibacterial activity of plant extracts through agar diffusion technique: In the reading of the growth inhibition zones (IZ) diameters (Table 1), the extracts from the stem and root of $B$. pilosa were inactive, and the extracts from the flower and leaf of $B$. 


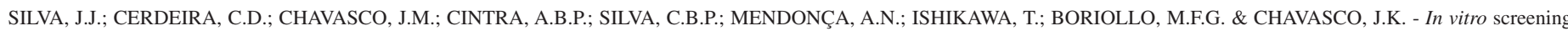
antibacterial activity of Bidens pilosa Linné and Annona crassiflora Mart. against Oxacillin Resistant Staphylococcus aureus (ORSA) from the aerial environment at the dental clinic. Rev. Inst. Med. Trop. Sao Paulo, 56(4): 333-40, 2014.

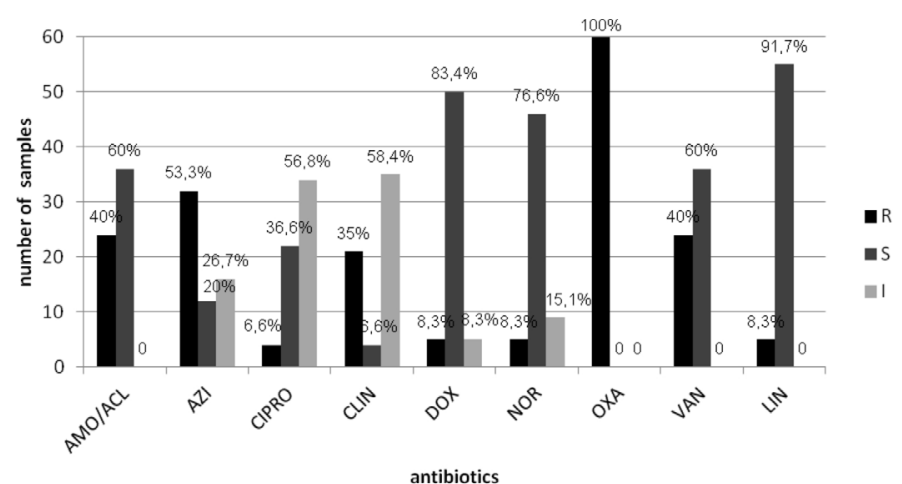

Fig. 2 - Profile of the sensitivity from the 60 samples isolated from aerial environment at the dental care clinic to antibiotics commonly utilized for treating $S$. aureus infections. AMO/ACL: amoxicillin with clavulanic acid (30); AZI: Azithromycin (15); CIPRO: Ciprofloxacin (05); CLIN: Clindamycin (02); DOX: doxycycline (30); NOR: Norfloxacin (10), OXA: Oxacillin (10); VAN: Vancomycin (30); LIN: Linezolid (30). R: Resistant ; S: Sensitive; I: Intermediate.

pilosa were effective against the 60 samples analyzed with an interval of IZ diameters ranging from eight to 23 millimeters (mm). For $A$. crassiflora, extracts from the stems, pulp, rind fruit and leaf were actives against ORSA with IZ diameters that ranged from five to $15 \mathrm{~mm}$. It was verified for the extracts from the B. pilosa and A. crassiflora there were better activities through the agar diffusion method as against $S$. aureus ATCC than on ORSA samples. The extract from the leaf of $B$. pilosa had the highest mean of the inhibition zone (IZ) diameters (17 $\mathrm{mm})$ against ORSA samples used in the experiment $(\mathrm{n}=60)$, followed by extract from the flower of B. pilosa $(14 \mathrm{~mm})$ (statistically significant with $p<0.05)$. Moreover, extract from the leaf of $B$. pilosa was the most active against $S$. aureus ATCC, and on ORSA as well, although the mean of the IZ diameters values for this extract on ATCC $(26 \mathrm{~mm})$ was statistically different from that presented against ORSA $(17 \mathrm{~mm})$ $(p<0.05)$. Against ORSA, only extracts from the leaf of B. pilosa demonstrated inhibitory activity significantly better than those presented for chlorhexidine $0.12 \%$ (positive control), which had a mean of the IZ diameters values of $15 \mathrm{~mm}$. Otherwise, against standard strain, the extracts from the leaf and flower of B. pilosa $(26$ and $22 \mathrm{~mm})$ and rind fruit of $A$. crassiflora $(18 \mathrm{~mm})$ were more active than positive control $(16 \mathrm{~mm})(p<0.05)$. In general, when comparing the activities of all extracts against $S$. aureus ATCC and against the isolates of ORSA, the overall mean of IZ diameters against ATCC was higher than against ORSA, so the extracts were more active against the standard strain than on the isolates $(p<0.05)$.

Determination of Minimum Inhibitory Concentration (MIC): The obtained results of MIC values are shown in Table 1, where the extracts from the stem of $B$. pilos $a$ high MIC values $(50 \mathrm{mg} / \mathrm{mL})$ against ORSA can be observed. On the other hand, for the extracts from the leaf and flower, the inhibition of the ORSA isolates with MIC values of 6.25 and 12.5 respectively was verified. For the extracts from the leaf and flower of $B$. pilosa, the MIC values were 25 and 1.56 respectively against $S$. aureus ATCC. For A. crassiflora, all extracts presented MIC values close to the maximum concentration used $(50 \mathrm{mg} / \mathrm{mL})$. The extracts from

Table 1

Interval and mean of the growth inhibition zone (IZ) diameters, MIC values, assessment of toxicity, and qualitative results of the phytochemical analysis of hidroethanolics extracts from the Bidens pilosa Linné and Anonna crassiflora Mart

\begin{tabular}{|c|c|c|c|c|c|c|c|c|c|c|c|c|c|c|}
\hline \multirow{2}{*}{ Species } & \multirow{2}{*}{ Extract } & \multicolumn{2}{|c|}{$\begin{array}{l}\text { Interval and mean }{ }^{1,2,3} \text { of the } \\
\text { IZ diameters }(\mathrm{mm})\end{array}$} & \multicolumn{2}{|c|}{$\mathrm{MIC}(\mathrm{mg} / \mathrm{mL})$} & \multicolumn{2}{|c|}{$\begin{array}{l}\text { Assessment of } \\
\text { toxicity }\end{array}$} & \multicolumn{2}{|c|}{ Selectivity Index (SI) } & \multicolumn{5}{|c|}{ Secondary metabolites } \\
\hline & & $\mathrm{ORSA}^{4}$ & $\begin{array}{c}\text { S. aureus } \\
\text { ATCC } 6538\end{array}$ & ORSA & $\begin{array}{c}\text { S. aureus } \\
\text { ATCC } 6538\end{array}$ & $\begin{array}{c}\mathrm{CC}_{50} \\
(\mathrm{mg} / \mathrm{mL})\end{array}$ & $\begin{array}{c}\mathrm{CC}_{90} \\
(\mathrm{mg} / \mathrm{mL})\end{array}$ & ORSA & $\begin{array}{c}\text { S. aureus } \\
\text { ATCC } 6538\end{array}$ & $\mathrm{Al}$ & An & $\mathrm{Fl}$ & $\mathrm{Ta}$ & $\mathrm{Sa}$ \\
\hline \multirow{4}{*}{$\begin{array}{l}\text { Bidens } \\
\text { pilosa }\end{array}$} & Root & $0(0)^{\mathrm{a}}$ & $0(0)^{\mathrm{a}}$ & $\mathrm{N}$ & $\mathrm{N}$ & NT & NT & NA & NA & - & - & - & + & + \\
\hline & Stem & $0(0)^{\mathrm{a}}$ & $0(0)^{\mathrm{a}}$ & 50 & 25 & 3.91 & 7.27 & 0.078 & 0.156 & + & - & - & + & + \\
\hline & Flower & $8-20(14)^{\mathrm{e}}$ & $21-23(22)^{\mathrm{i}}$ & 12.5 & 1.56 & 2.82 & 5.41 & 0.226 & 1.808 & + & - & + & + & + \\
\hline & Leaf & $8-23(17)^{g}$ & $25-28(26)^{\mathrm{j}}$ & 6.25 & 25 & NT & NT & NA & NA & + & - & + & + & + \\
\hline \multirow{5}{*}{$\begin{array}{l}\text { Anonna } \\
\text { crassiflora }\end{array}$} & Rind fruit & $6-15(12)^{d}$ & $16-20(18)^{\mathrm{h}}$ & 50 & 6.25 & 2.06 & 9.38 & 0.041 & 0.330 & + & - & - & + & - \\
\hline & Stem & $5-15(9)^{\mathrm{b}}$ & $10-14(12)^{\mathrm{d}}$ & 25 & 1.56 & 5.86 & 10.77 & 0.234 & 3.756 & - & - & - & + & - \\
\hline & Seed & $0(0)^{\mathrm{a}}$ & $0(0)^{\mathrm{a}}$ & 50 & $\mathrm{~N}$ & NT & NT & NA & NA & - & - & - & - & - \\
\hline & Pulp & $6-15(9)^{b}$ & $14-18(16)^{\mathrm{f}}$ & 25 & 12.5 & 2.68 & 5.98 & 0.107 & 0.214 & + & - & - & - & + \\
\hline & Leaf & $6-14(10)^{c}$ & $10-14(12)^{\mathrm{d}}$ & 25 & 25 & 3.86 & 8.03 & 0.154 & 0.154 & + & - & + & - & - \\
\hline \multirow{2}{*}{ Controls } & $\begin{array}{c}\text { Chlorexidine } \\
0.12\end{array}$ & $10-26(15)^{\mathrm{f}}$ & $15-18(16)^{\mathrm{f}}$ & NA & NA & NA & NA & NA & NA & NA & NA & NA & NA & NA \\
\hline & $\begin{array}{l}\text { Distilled } \\
\text { water }\end{array}$ & $0(0)^{\mathrm{a}}$ & $0(0)^{\mathrm{a}}$ & NA & NA & NA & NA & NA & NA & NA & NA & NA & NA & NA \\
\hline
\end{tabular}

${ }^{1}$ Between parenthesis; ${ }^{2}$ means followed by same letter show no statistic difference each other according to Scott \& Knott test at $5 \%$ of significance $(\alpha=0.05) ;{ }^{3}$ All tests by agar diffusion with the extracts at a concentration of $100 \mathrm{mg} / \mathrm{mL} ;{ }^{4} \mathrm{n}=60$ samples; MIC: Minimum inhibitory concentration; $\mathrm{CC}_{50}: 50 \%$ cytotoxic concentration; $\mathrm{CC}_{90}: 90 \%$ cytotoxic concentration; $\mathrm{SI}=\mathrm{CC}_{50} / \mathrm{MIC} ; \mathrm{N}=$ absence of inhibition at the maximal concentration used; NT= Non-toxic at the concentrations used; $\mathrm{NA}=\mathrm{Not}$ applicable to this analysis; Al: Alkaloids; An: Anthraquinones; Fl: Flavonoids; Ta: Tannins; Sa: Saponins; + : positive reaction; - : negative reaction. 


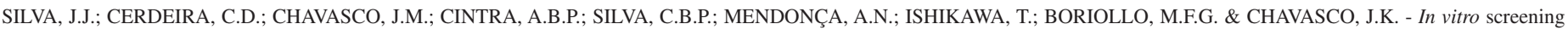

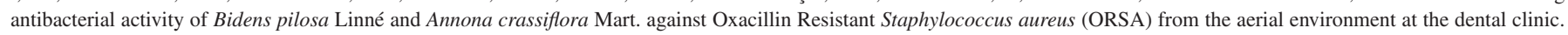
Rev. Inst. Med. Trop. Sao Paulo, 56(4): 333-40, 2014.

the stem of A. crassiflora and flower of B. pilosa presented the lowest MIC values against $S$. aureus ATCC $(1.56 \mathrm{mg} / \mathrm{mL})$.

Phytochemical evaluation of plant extracts: The phytochemical profiles of the extracts (Table 1 ) revealed that all extracts from the $B$. pilosa were positive for tannins and saponins, and almost all were positive for alkaloids (three in four extracts). For A. crassiflora, the variable presence of alkaloids, flavonoids, tannins and saponins was evidenced. All extracts (from the $B$. pilosa and A. crassiflora) were negative for anthraquinones.

Evaluation of cytotoxic activity of extracts on cell culture: Parallel analysis was held for evaluation of cytotoxicity of the extracts. In the examination carried out on cell culture, in accordance with Table 1 , the extracts from the leaf and root of $B$. pilosa showed no toxicity in the concentrations tested on cell culture. On the other hand, the 50\% cytotoxic concentration $\left(\mathrm{CC}_{50}\right)$ ranged from $1.30 \mathrm{mg}$ to $9.56 \mathrm{mg} / \mathrm{mL}$ for all others extracts. The $90 \%$ cytotoxic concentration $\left(\mathrm{CC}_{90}\right)$ ranged from 2.55 to $19.00 \mathrm{mg} / \mathrm{mL}$. For A. crassiflora, the $\mathrm{CC}_{50}$ and $\mathrm{CC}_{90}$ ranged from 2.06 to 5.86 and from 5.93 to 10.77 respectively. For the extract from the seed, it was verified there was no toxicity in the concentration tested. According to PROTOPOPOVA et al. ${ }^{47}$ the selectivity index (SI) is calculated as the ratio between the $\mathrm{CC}_{50}$ and the MIC. The values found were lower in the analysis against ORSA. For the IS values against the standard strain, the most satisfactory was 3.756 for the extract from the stem of A. crasssiflora.

\section{DISCUSSION}

The ORSA samples analyzed in this experiment are from the environment at the dental care clinic (air), where the transmission of pathogens is intense due to the instrumentation used, such as high speed instruments. These factors make the dental clinical environment as prone to cross-contamination and/or cross-transmission for $S$. aureus, as in a hospital environment ${ }^{46,62}$. It can lead to contamination and infection of patients. The profile of the sensitivity (Fig. 1) for the ORSA samples analyzed strengthens previous studies, which indicate a massive dissemination of the multiresistant $S$. aureus, in which most strains of ORSA exhibit high level resistance to commercially available antimicrobial agents. Furthermore, $S$. aureus remains a major cause of nosocomial disease ${ }^{15}$ and recent reports have indicated that the epidemiology of ORSA may be undergoing a change through the emergence of community-acquired infections ${ }^{27}$. Until recently, vancomycin has been used to treat ORSA infections, and the failure in the treatment with vancomycin and other antimicrobial agents has been reported, raising concerns that treatment of ORSA infections has become even more problematic and has led to higher rates of morbidity and mortality throughout the world ${ }^{1,15,59}$. Therefore, there is a need to search for new therapies. Previous studies have related the importance of plants as a source of compounds with antimicrobial activity or provide a viable therapeutic strategy as phytomedicines ${ }^{36,48,61,63}$.

In this work, the anti-ORSA activity of the extracts from the different parts of $B$. pilosa and A. crassiflora were evaluated through the agar diffusion method and broth microdilution. In the evaluation through the agar diffusion method, it has shown a ranging interval of the IZ diameters for each extract against the 60 ORSA isolates (Table 1). This may be at least partly explained as a result of morphophysiological differences, derived from the specific genetics of the samples ${ }^{1,3,19,20}$. Despite the reproducibility of the results through the diffusion method in the Mueller-Hinton Agar ${ }^{12}$, nowadays it is known that in the evaluation of the antimicrobial activity of plant extracts, which are complex blends, through agar diffusion, several factors can influence the IZ diameters values and the reproducibility remains controversial ${ }^{45}$. In addition, because of the extracts, depletion or destruction of the compounds of the culture medium can occur, inhibiting the microorganisms; therefore, perhaps the antimicrobial action did not result from a direct interaction between the extracts and the microorganisms.

Regarding the diffusion agar method, there are a large number of scientific studies highlighting the antibacterial properties of plants ${ }^{14}$. MATTANA et al..$^{34}$ observed resistant $S$. aureus to methicillin highly susceptible to ethyl acetate and ethanol extracts of Acacia aroma, through the agar diffusion method. It also observed that ethanol extracts showed greater antimicrobial activity compared to extracts which had only water as a solvent. The extracts used in this study have undergone maceration through ethyl alcohol $70 \%$ and an excellent antibacterial performance by agar diffusion was observed, thus confirming the assertion described by MATTANA et al. ${ }^{34}$, probably due to the alcohol that extracts greater numbers of polar and nonpolar substances. Additionally, the difference of solubility for each extract can be an influence during the diffusion in agar, where extracts with the greatest concentrations of more polar substances show better diffusion than those richer in non-polar substances. In our study, the extracts were more active against the standard strain of $S$. aureus than against the ORSA isolates, and the extract from the leaf of B. pilosa was the most active by agar diffusion $(p<0.05)$.

In the determination of MIC (Table 1) by using broth microdilution, it was found that the extract from the stem of $B$. pilosa showed MIC value of $50 \mathrm{mg} / \mathrm{mL}$ and, in this sense, the antibacterial activity of this extract should be taken into account with the cytotoxic activity, aiming either studies for bioassay-guided fractionation of novel compounds or likewise to studies of the quality, effectiveness and safety of herbal medicinal preparations ${ }^{63}$.

The extracts from the leaf and flower of B. pilosa showed inhibition results at lower concentrations. FABRI et al. ${ }^{21}$ reported the antimicrobial activity of members of the family Asteraceae, to which $B$. pilos $a$ belongs. Despite the extracts from the stem of $B$. pilos $a$ and the seed of $A$. crassiflora at a concentration of $100 \mathrm{mg} / \mathrm{mL}$ no evidenced antibacterial activity through the agar diffusion method was observed; MIC values of $50 \mathrm{mg} / \mathrm{mL}$ were verified, in both cases. In accordance with HADECEK \& GREGER ${ }^{25}$, it is acknowledged that the broth microdilution presents higher sensitivity than the agar diffusion method, by allowing direct contact between the compound, the medium and the microorganisms, so that the inactivity of the extracts through the agar diffusion parallel the activity by broth microdilution, probably occurring due to this.

MATTANA et al. ${ }^{34}$ related the activity of organic extracts of Acacia aroma against ORSA with MICs that ranged from 2.5 to $10 \mathrm{mg} / \mathrm{mL}$. The MIC values for Hyptis martiusii on MRSA and MSSA (methicillin sensitive $S$. aureus) developed by COUTINHO et al. ${ }^{14}$ ranged from 128 to $\geq 1024 \mathrm{mg} / \mathrm{mL}$, values greater than that found in our study. Analyzing the results of MIC in Table 1, in general, the extracts evaluated showed higher MIC values against ORSA when compared with the values found against the standard strain sensitive to oxacillin $S$. aureus. Only the extract 


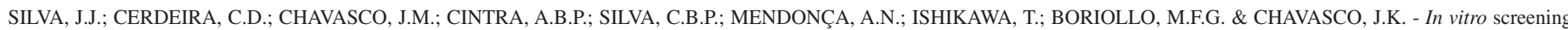
antibacterial activity of Bidens pilosa Linné and Annona crassiflora Mart. against Oxacillin Resistant Staphylococcus aureus (ORSA) from the aerial environment at the dental clinic. Rev. Inst. Med. Trop. Sao Paulo, 56(4): 333-40, 2014.

from the leaf of $B$. pilosa had low MIC values on ORSA $(6.25 \mathrm{mg} / \mathrm{mL})$ when comparing those presented against a standard strain $(25 \mathrm{mg} / \mathrm{mL})$.

As for the phytochemical profile, it was observed that, among extracts, there was a total absence of anthraquinones and the variable presence of alkaloids, flavonoids, tannins, and saponins. It confirms previous studies in which such compounds are commonly isolated from these plants ${ }^{7,8,30}$.

A. crassiflora extracts showed the presence of alkaloids in rind fruit, pulp and leaf extracts. In 1982, LEBOEUF et al. ${ }^{30}$ published a review about the Annonaceae phytochemical family, where the predominance of aporphine and oxoaporphine alkaloids among secondary metabolites isolated from species belonging to the family was reported. It was observed that the extracts from the stem and fruit bark presented tannins. Saponins were observed only in the pulp extract and flavonoids only in leaf extract. Besides alkaloids, constituents like polyphenols, essential oils, terpenes and aromatic substances are also found in family representatives ${ }^{30}$. Regarding the phenolic compounds in the Annonaceae family the most frequent ones are flavonoids ${ }^{57}$.

Analysis of B. pilosa revealed that the majority of the extracts showed positive for alkaloids, flavonoids, tannins and saponins. This result confirms previous studies which state that the main compounds already isolated from the plant are poliacetylenic and flavonoid substances ${ }^{8}$. BORGES ${ }^{7}$ also determined the presence of phenolic compounds such as tannins and flavonoids, and also showed positive results for saponins and alkaloids, which are results observed in this study. In addition, researches have reported that alkaloids, flavonoids, tannins and saponins are implicated in the antimicrobial action ${ }^{9,17,53,54}$. So, the activity found in our study for the plants evaluated could be associated with the presence of these compounds ${ }^{26}$.

Concerning the inactivity or antimicrobial activity of the extracts and the presence of metabolites mentioned, the complexity of plant extracts should not be overlooked, being the final response (antibacterial activity) result of synergistic, antagonistic and other interactive effects among their bioactive components ${ }^{61}$. Previous studies have reported the antimicrobial activity for the metabolite isolated, and in the case of the study with crude extracts, interactions between the compounds must be considered possible. Notwithstanding this, the antimicrobial activity presented could be mediated at least partly by the compounds from the extracts, which could affect the morphophysiology of the microorganism.

With the results of the assessment of toxicity (Table 1), it can be observed that extract from the leaf of $B$. pilosa showed a desirable characteristic among the extracts because it showed no toxic at the concentration utilized, besides presenting a lower MIC $(6.25 \mathrm{mg} / \mathrm{mL})$ against ORSA, with a good chance of application in further studies by bio-prospection. The extract from the stem of A. crassiflora proved to be the more toxic. As to the selectivity, extract from the stem of A. crassiflora showed the better selectivity index (SI) against ORSA (0.234), and on standard strain (3.756).

In summary, the extracts from the flower and leaf of Bidens pilosa; and rind fruit, pulp, stem and leaf of A. crassiflora inhibited the growth of the ORSA isolates by both methods tested; however, extracts from the root of B. pilosa and seed of A. crassiflora displayed no antimicrobial activity.
As for the toxicity, some extracts did not show toxicity. Therefore, a good extract due to the fact that it showed lower MIC and no toxic effect was the extract from the leaf of $B$. pilosa. Further studies must be realized, in order to identify and isolate compounds responsible for this activity and understand how they exercise this effect on the Staphylococcus species.

\section{RESUMO}

Triagem in vitro da atividade antibacteriana de Bidens pilosa Linné e Annona crassiflora Mart. contra Staphylococcus aureus resistente à oxacilina (ORSA) provenientes do ambiente aéreo na clínica odontológica

Atualmente Staphylococcus aureus multirresistente é causa comum de infecções com altas taxas de morbidade e mortalidade mundialmente, o que direciona esforços científicos na busca de novos antimicrobianos. Neste estudo, nove extratos de Bidens pilosa (raiz, caule, flor e folhas) e de Annona crassiflora (casca do fruto, caule, folha, semente e polpa) foram obtidos com etanol:água (7:3, v/v) e suas atividades antibacteriana in vitro avaliadas através de difusão em agar e microdiluição em caldo contra 60 cepas de Oxacillin Resistant $S$. aureus (ORSA) e contra $S$. aureus ATCC 6538. Os extratos de B. pilosa e A. crassiflora inibiram o crescimento dos isolados ORSA em ambos os métodos. O extrato da folha de $B$. pilosa apresentou média dos diâmetros dos halos de inibição significativamente maior que a clorexidina $0,12 \%$, contra os isolados ORSA, e os extratos foram mais ativos contra $S$. aureus ATCC $(p<$ $0,05)$. Paralelamente, teste de toxicidade pelo método MTT e triagem fitoquímica foram avaliadas, e três extratos (raiz e folha de B. pilosa e semente de $A$. crassiflora) não apresentaram toxicidade. Por outro lado, as concentrações citotóxicas $\left(\mathrm{CC}_{50} \mathrm{e} \mathrm{CC}_{90}\right)$ para os outros extratos variaram de 2,06 a 10,77 mg/mL. Observou-se variável presença de alcalóides, flavonóides, taninos e saponinas, apesar de total ausência de antraquinonas. Portanto, os extratos das folhas de B. pilosa revelaram boa atividade anti-ORSA e não exibiram toxicidade.

\section{ACKNOWLEDGEMENTS}

The authors acknowledge Dr. Marcelo Polo for the identification of the plant material. This research was supported by FAPEMIG (Fundação de Amparo à Pesquisa do Estado de Minas Gerais - APQ-3897-4.03/07).

\section{REFERENCES}

1. Aires de Sousa M, de Lencastre H. Bridges from hospitals to the laboratory: genetic portraits of methicillin-resistant Staphylococcus aureus clones. FEMS Immunol Med Microbiol. 2004;40:101-11

2. Araújo SAC, Teixeira MFS, Dantas TVM, Miranda AM, Lima FES, Melo VSP, et al. Avaliação in vitro da atividade citotóxica de drogas antivirais em fibroblastos caprinos. Cienc Anim. 2008;18:25-31.

3. Ayliffe GAJ. The progressive intercontinental spread of methicillin resistant Staphylococcus aureus. Clin Infect Dis. 1997;24(Suppl 1):S74-S9.

4. Bauer AW, Kirby WMM, Sherris JC, Turck M. Antibiotic susceptibility testing by a standardized single disk method. Am J Clin Pathol. 1966;45:493-6.

5. Barbosa-Filho JM, Nascimento-Júnior FA, Tomaz ACA, Athayde-Filho PF, Silva MS, Cunha EVL, et al. Natural products with antileprotic activity. Rev Bras Farmacogn. 2007; 17:141-8. 


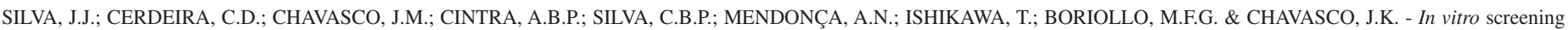

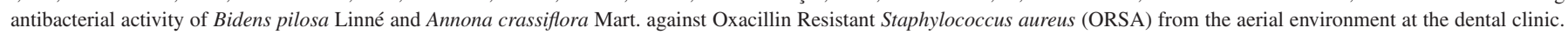
Rev. Inst. Med. Trop. Sao Paulo, 56(4): 333-40, 2014.

6. Bell JM, Turnidge JD. High prevalence of oxacillin-resistant Staphylococcus aureus isolates from hospitalized patients in Asia-Pacific and South Africa: results from SENTRY Antimicrobial Surveillance Program, 1998-1999. Antimicrob Agents Chemother. 2002;46:879-81.

7. Borges CC. Análise farmacognóstica de Bidens pilosa (1.) (Asteraceae) [monografia] Criciúma: Universidade do Extremo Sul Catarinense, Faculdade de Farmácia; 2009.

8. Brandão MGL, Krettli AU, Soares LSR, Nery CGC, Marinuzzi HC. Antimalarial activity of extracts and fractions from Bidens pilosa and other Bidens species (Asteraceae) correlated with the presence of acetylene and flavonoid compounds. J Ethnopharmacol. 1997;57:131-8.

9. Bruneton J. Pharmacognosy, phytochemistry, medicinal plants. $2^{\text {nd }}$ ed. Paris: Lavoisier Publishing/Intercept; 1999.

10. Chang JS, Chiang LC, Chen CC, Liu LT, Wang KC, Lin CC. Antileukemic activity of Bidens pilosa L. var. minor (Blume) Sherff and Houttuynia cordata Thunb. Am J Chin Med. 2001;29:303-12

11. Chiang LC, Cheng HY, Liu MC, Chiang W, Lin CC. In vitro anti-herpes simplex viruses and anti-adenoviruses activity of twelve traditionally used medicinal plants in Taiwan. Biol Pharm Bull. 2003;26:1600-4

12. Clinical and Laboratory Standards Institute (CLSI). Methods for dilution antimicrobial susceptibility tests for bacteria that grow aerobically. Approved standard M7-A6. $6^{\text {th }}$ ed. Wayne: NCCLS; 2003.

13. Costa AF. Isolamento e identificação dos constituintes vegetais. In: Farmacognosia Lisboa: Fundação Calouste Gulbenkian; 1982. vol. 3. p. 926-62.

14. Coutinho HDM, Costa JGM, Siqueira-Júnior JP, Lima EO. In vitro anti-staphylococcal activity of Hyptis martiusii Benth against methicillin-resistant Staphylococcus aureusMRSA strains. Rev Bras Farmacogn. 2008;18(Suppl):670-5.

15. Cordeiro JCR, Reis AO, Miranda EA, Sader HS. In vitro antimicrobial activity of the aminoglycoside arbekacin tested against oxacillin-resistant Staphylococcus aureus isolated in Brazilian hospitals. Braz J Infect Dis. 2001;5:130-5.

16. Cortés-Rojas DF, Chagas-Paula DA, da Costa FB, Souza CRF, Oliveira WP. Bioactive compounds in Bidens pilosa L. populations: a key step in the standardization of phytopharmaceutical preparations. Rev Bras Farmacogn. 2013;23:28-35.

17. Cowan MM. Plant products as antimicrobial agents. Clin Microbiol Rev. 1999;12: 564-82.

18. Deba F, Xuan TD, Yasuda M, Tawata S. Chemical composition and antioxidant, antibacterial and antifungal activities of the essential oils from Bidens pilosa Linn. var. radiata. Food Control. 2008;19:346-52.

19. Deurenberg RH, Vink C, Kalenic S, Friedrich AW, Bruggeman CA, Stobberingh EE. The molecular evolution of methicillin-resistant Staphylococcus aureus. Clin Microbiol Infect. 2007;13:222-35

20. Dos Santos Soares MJ, da Silva-Carvalho MC, Ferreira-Carvalho BT, Figueiredo AM Spread of methicillin-resistant Staphylococcus aureus belonging to the Brazilian epidemic clone in a general hospital and emergence of heterogenous resistance to glycopeptide antibiotics among these isolates. J Hosp Infect. 2000;44:301-8.

21. Fabri RL, Nogueira MS, Dutra LB, Bouzada MLM, Scio E. Potencial antioxidante e antimicrobiano de espécies da família Asteraceae. Rev Bras Pl Med. 2011;13:183-9.

22. Galati G, O'Brien PJ. Potential toxicity of flavonoids and other dietary phenolics: significance for their chemopreventive and anticancer properties. Free Radical Biol Med. 2004;37:287-303.

23. Geissberger P, Séquin U. Constituents of Bidens pilosa L.: do the components found so far explain the use of this plant in traditional medicine? Acta Trop. 1991;48:251-61.
24. Gelatti LC, Bonamigo RR, Becker AP, D'Azevedo PA. Staphylococcus aureus resistentes a meticilina: disseminação emergente na comunidade. An Bras Dermatol. 2009;84:501-6.

25. Hadecek F, Greger H. Testing of antifungal natural products: methodologies, comparability of results and assay of choice. Phytochem Anal. 2000;11:137-47.

26. Ho KY, Tsai CC, Huang HS, Chen CP, Lin TC, Lin CC. Antimicrobial activity of tannin components from Vaccinium vitis-idaea L. J Pharm Pharmacol. 2001;53:187-91.

27. Hou Z, Meng JR, Zhao JR, Hu BQ, Liu J, Yan XJ, et al. Inhibition of $\beta$-lactamase-mediated oxacillin resistance in Staphylococcus aureus by a deoxyribozyme. Acta Pharmacol Sin. $2007 ; 28: 1775-82$

28. Khan MR, Kihara M, Omoloso AD. Antimicrobial activity of Bidens pilosa, Bischofia javanica, Elmerillia papuana and Sigesbekia orientalis. Fitoterapia. 2001;72:662-5.

29. Kviecinski MR, Felipe KB, Schoenfelder T, de Lemos Wiese LP, Rossi MH, Gonçalvez E, et al. Study of the antitumor potential of Bidens pilosa (Asteraceae) used in Brazilian folk medicine. J Ethnopharmacol. 2008;117:69-75.

30. Leboeuf M, Cavé A, Bhaumik PK, Mukherjee B, Mukherjee R. The phytochemistry of the Annonaceae. Phytochemistry. 1982; 21:2783-813.

31. Leitão SG, Castro O, Fonseca EN, Julião LS, Tavares ES, Leo RRT, et al. Screening of Central and South American plant extracts for antimycobacterial activity by the Alamar Blue test. Rev Bras Farmacogn. 2006;16:6-11.

32. Lima IO, Oliveira RAG, Lima EO, Farias NMP, Souza EL. Atividade antifúngica de óleos essenciais sobre espécies de Candida. Rev Bras Farmacogn. 2006;16:197-201.

33. Masunari A, Tavares LC. Aplicação de estudos de QSAR-2D em derivados 5-nitro2-tiofilidênicos com atividade antimicrobiana frente a Staphylococcus aureus multiresistente (MRSA). Rev Bras Cienc Farm. 2006;42:203-14.

34. Mattana CM, Satorres SE, Sosa A, Fusco M, Alcará LE. Antibacterial activity of extracts of Acacia aroma against methicillin-resistant and methicillin-sensitive Staphylococcus. Braz J Microbiol. 2010;41:581-7.

35. McDougal LK, Steward CD, Killgore GE, Chaitram JM, McAllister SK, Tenover FC Pulsed-field gel electrophoresis typing of oxacillin-resistant Staphylococcus aureu isolates from the United States: establishing a national database. J Clin Microbiol. 2003;41:5113-20.

36. Meng JC, Zhu QX, Than RX. New antimicrobial mono and sesquiterpenes from Soroseris hookeriana subsp. erysimoides. Planta Med. 2000;66:541-4.

37. Michelin DC, Moreschi PE, Lima AC, Nascimento GGF, Paganelli MO, Chaud MV. Avaliação da atividade antimicrobiana de extratos vegetais. Rev Bras Farmacogn. $2005 ; 15: 316-20$

38. Morre DJ, de Cabo R, Farley C, Oberlies NH, McLaughlin JL. Mode of action of bullatacin, a potent antitumor acetogenin: inhibition of NADH oxidase activity of HELa and HL-60, but not liver, plasma membranes. Life Sci. 1995;56:343-8.

39. Moreira MR, Cardoso RL, Almeida AB, Gontijo Filho PP. Risk factors and evolution of ventilator-associated pneumonia by Staphylococcus aureus sensitive or resistant to oxacillin in patients at the intensive care unit of a Brazilian university hospital. Braz J Infect Dis. 2008;12:499-503.

40. Motsei ML, Lindsey KL, Van Staden J, Jäger AK. Screening of traditionally used South African plants for antifungal activity against Candida albicans. J Ethnopharmacol. 2003;86:235-41.

41. Nadarajah J, Lee MJ, Louie L, Jacob L, Simor AE, Louie M, et al. Identification of differen clonal complexes and diverse amino acid substitutions in penicillin-binding protein 2 (PBP2) associated with borderline oxacillin resistance in Canadian Staphylococcus aureus isolates. J Med Microbiol. 2006;55:1675-83. 
SILVA, J.J.; CERDEIRA, C.D.; CHAVASCO, J.M.; CINTRA, A.B.P.; SILVA, C.B.P.; MENDONÇA, A.N.; ISHIKAWA, T.; BORIOLLO, M.F.G. \& CHAVASCO, J.K. - In vitro screening antibacterial activity of Bidens pilosa Linné and Annona crassiflora Mart. against Oxacillin Resistant Staphylococcus aureus (ORSA) from the aerial environment at the dental clinic. Rev. Inst. Med. Trop. Sao Paulo, 56(4): 333-40, 2014.

42. Nguelefack TB, Dimo T, Mbuyo EP, Tan PV, Rakotonirina SV, Kamanyi A. Relaxant effects of the neutral extract of the leaves of Bidens pilosa Linn on isolated rat vascular smooth muscle. Phytother Res. 2005;19:207-10.

43. Oberlies NH, Chang CJ, McLaughlin JL. Structure activity relationships of diverse Annonaceous acetogenins against multidrug resistant human mammary adenocarcinoma (MCF-7/Adr) cells. J Med Chem. 1997;40:2102-6.

44. Oliveira FQ, Andrade-Neto V, Krettli AU, Brandão MGL. New evidencies of antimalarial activity of Bidens pilosa roots extracts correlated with polyacetylene and flavonoids. J Ethnopharmacol. 2004;93:39-42.

45. Ostrosky EA, Mizumoto MK, Lima MEL, Kaneko TM, Nishikawa SO, Freitas BR. Métodos para avaliação da atividade antimicrobiana e determinação da concentração mínima inibitória (CMI) de plantas medicinais. Rev Bras Farmacogn. 2008;18:301-7.

46. Powell JP, Wenzel RP. Antibiotic options for treating community acquired MRSA. Expert Rev Anti Infect Ther. 2008;6:299-307.

47. Protopopova M, Hanrahan C, Nikonenko B, Samala R, Chen P, Gearhart J, et al. Identification of a new antitubercular drug candidate, SQ 109, from a combinatorial library of 1,2-ethylenediamines. J Antimicrob Chemother. 2005;56:968-74.

48. Rojas JJ, Ochoa VJ, Ocampo SA, Muñoz JF. Screening for antimicrobial activity of ten medicinal plants used in Colombian folkloric medicine: a possible alternative in the treatment of non-nosocomial infections. BMC Complement Altern Med. 2006;6:2.

49. Rupprechet JK, Hui YH, McLaughlin JL. Annonaceous acetogenins: a review. J Nat Prod. 1990;53:237-78.

50. Santos LP, Boaventura MAD, Sun NJ, Cassady MJ, Oliveira AB. Araticunlin, a bis-tetrahydrofuran polyketide from Annona crassiflora seeds. Phytochemistry. 1996;42:705-7.

51. Santos DY, Salantino ML. Foliar flavonoids of Annonaceae from Brazil: taxonomic significance. Phytochemistry. 2000;55:567-73.

52. Saúde-Guimarães DA, Faria AR. Substâncias da natureza com atividade anti-Trypanosoma cruzi. Rev Bras Farmacogn. 2007;17:455-65.

53. Scalbert A. Antimicrobial properties of tannins. Phytochemistry. 1991;30:3875-83.
54. Schenkel, EP, Gosmann, G, Athayde, ML. Saponinas. In: Simões, CM, Schenkel, EP, Gosmann, G, Mello, JCP, Mentz, LA, Petrovick, PR. Farmacognosia: da planta ao medicamento. 3. ed. Porto Alegre: Ed. UFRGS/Ed. UFSC; 2001. p. 27, p. 597- 619.

55. Scott AJ, Knott M. Cluster analysis method for grouping means in the analysis of variance. Biometrics. 1974;30:507-12.

56. Silva RB, Almeida CR, Chavasco JM, Chavasco JK. Antimycobacterial activity evaluation and MIC determination of liophilizated hydroalcoholic extracts Bixa orellana L., Bixaceae. Rev Bras Farmacogn. 2010;20:171-4.

57. Simões CMO, Schenkel EP. Farmacognosia: da planta ao medicamento. Florianópolis: Ed. da UFSC; 2004.

58. Teixeira LA, Resende CA, Ormonde LR, Rosenbaum R, Figueiredo AM, de Lencastre $\mathrm{H}$, et al .Geographic spread of epidemic multiresistant Staphylococcus aureus clone in Brazil. J Clin Microbiol. 1995;33:2400-4.

59. Tenover FC, Lancaster MV, Hill BC, Steward CD, Stocker SA, Hancock GA, et al. Characterization of staphylococci with reduced susceptibilities to vancomycin and other glycopeptides. J Clin Microbiol. 1998;36:1020-7.

60. Velasco D, del Mar Tomas M, Cartelle M, Beceiro A, Perez A, Molina F, et al. Evaluation of different methods for detecting methicillin (oxacillin) resistance in Staphylococcus aureus. J Antimicrob Chemother. 2005;55:379-82.

61. Vilar JB, Ferreira FL, Ferri PH, Guillo LA, Chen Chen L. Assessment of the mutagenic, antimutagenic and cytotoxic activities of ethanolic extract of araticum (Annona crassiflora Mart. 1841) by micronucleus test in mice. Braz J Biol. 2008;68: 141-7.

62. Wallin TR, Hern HG, Frazee BW. Community-associated methicillin resistant Staphylococcus aureus. Emerg Med Clin North Am. 2008;26:431-55.

63. World Health Organization. Traditional medicine strategy 2002-2005. Geneva: WHO 2002. [cited 2013 Mar 10]. Available from: http://whqlibdoc.who.int/hq/2002/ who_edm_trm_2002.1.pdf

64. Zafra-Polo MC, Figadère B, Gallardo T, Tormo JR, Cortes D. Natural acetogenins from Annonaceae, synthesis and mechanisms of action. Phytochemistry. 1998; 48:1087117.

Received: 11 April 2013

Accepted: 27 January 2014 